\title{
Microbial Carbon, Mineral-N and Soil Nutrients in Indigenous Agroforestry Systems and Other Land Use in the upper Solimões Region, Western Amazonas State, Brazil
}

\author{
Fernanda Tunes Villani', Gyovanni Augusto Aguiar Ribeiro1, \\ Ecila Mercês de Albuquerque Villani' ${ }^{2}$, Wenceslau Geraldes Teixeira3, \\ Fatima Maria de Souza Moreira ${ }^{4}$, Robert Miller ${ }^{5}$, Sonia Sena Alfaia ${ }^{6 *}$ \\ ${ }^{1}$ Departamento de Química e Meio Ambiente, Instituto Federal de Educação, Ciência e Tecnologia, Manaus, Brazil \\ ${ }^{2}$ Universidade Federal de Viçosa, Viçosa, Brazil \\ ${ }^{3}$ Departamento de Solos, Embrapa Solos, Empresa Brasileira de Pesquisa Agropecuária, Rio de Janeiro, Brazil. \\ ${ }^{4}$ Departamento de Ciência do Solo, Universidade Federal de Lavras, Lavras, Brazil \\ ${ }^{5}$ United Nations Development Program, Brasília, Brazil \\ ${ }^{6}$ Coordenação de Tecnologia e Inovação, Instituto Nacional de Pesquisas da Amazônia, Manaus, Brazil \\ Email: *sonia.alfaia@in pa.gov.br
}

How to cite this paper: Villani, F.T., Ribeiro, G.A.A., Villani, E.M.A., Teixeira, W.G., Moreira, F.M.S., Miller, R. and Alfaia, S.S. (2017) Microbial Carbon, Mineral-N and Soil Nutrients in Indigenous Agroforestry Systems and Other Land Use in the upper Solimões Region, Western Amazonas State, Brazil. Agricultural Sciences, 8, 657-674.

https://doi.org/10.4236/as.2017.87050

Received: June 1, 2017

Accepted: July 25, 2017

Published: July 28, 2017

Copyright $\odot 2017$ by authors and ScientificResearch Publishing Inc. This work is licensed under the CreativeCommons Attribution International License (CC BY 4.0).

http://creativecommons.org/licenses/by/4.0/ (c) (i) Open Access

\begin{abstract}
Slash and burn cultivation systems carried out by many farmers in the Amazon region lead to changes in biogeochemical cycles of nutrients. To assess the extent of the impact of shifting cultivation on the soil in a floodplain portion of this region, samples of an Inceptisol surface layer $(0-5 \mathrm{~cm})$ under primary forest (FP), secondary forest at an advanced stage of recovery (FS), secondary forest at an initial stage of recovery (CAP), agroforestry (SAF), plantations (RÇ) in indigenous communities and small farmers, and pasture (PAS) in the Upper Solimões region, Amazonas, were subjected to analysis of chemical composition during the wet (May) and dry (October) seasons, 2007. Soils were fertile with levels of $\mathrm{P}, \mathrm{K}, \mathrm{Ca}$ and $\mathrm{Mg}$ above those generally found in Amazon soils. Microbial content did not vary significantly in the systems studied in the wet season, but there was a reduction of around $60 \%$ with the change of season, except for soils with SAF. Ammonium nitrogen was predominant in all systems and seasons studied. Nitrate content was higher in RÇ soil, in two seasons, and lower in PAS. The type of management adopted by farmers in the region's indigenous agroforestry systems resulted in small changes in $\mathrm{P}, \mathrm{K}, \mathrm{Mg}, \mathrm{MBC}$ and mineral-N levels, independent of soil moisture.
\end{abstract}

\section{Keywords}

Traditional Agriculture, Soil Management, Primary and Secondary Forests, 
Pasture, Inceptisol

\section{Introduction}

Amazon rain forest soils are thought to have a very high microbial biodiversity, since they support one of the most species rich ecosystems on the planet. However, forms of soil preparation and cultivation such as slash and burn commonly used in this region lead to changes in biogeochemical cycles, especially carbon (C) and nitrogen $(\mathrm{N})[1]$ [2].

To monitor soil quality, particularly in agroforestry systems, the analysis of a combination of attributes is necessary as a basis to study land use sustainability. Soil quality is the most important link between agricultural practices and sustainable agriculture [3]. In this regard, indigenous people and small-scale farmers in the Amazon who use practices of slash and burn have been encouraged to adopt techniques that promote nutrient cycling and maintain soil organic matter (SOM) in order to conserve or improve soil quality.

The literature reports that SOM is the attribute which best represents the quality of soil since it influences several factors: biota, nutrient availability, soil structure, erosion and water availability [4]. The microbial biomass is an SOM compartment which proportionally represents the smallest fraction of soil organic $\mathrm{C}$, but is a significant and potentially mineralizable source of $\mathrm{N}$ available to plants [5], showing fast nutrient cycling and responding intensely to seasonal fluctuations in humidity and temperature, farming practices and management of plant residues [6]. Since the microbial biomass represents $2 \%-5 \%$ of the organic $\mathrm{C}$ of soil [7] and from $1 \%$ to $5 \%$ of the total $\mathrm{N}$ of soil [8], microbial $\mathrm{C}$ estimates can be used as a biological indicator of SOM levels, or as a soil quality index [9]. Microbial biomass is considered to be the most active part of the SOM in which the cycling of organic carbon is quick and its estimate is thus being used in studies of $\mathrm{C}$ and $\mathrm{N}$ flows, nutrient recycling and plant productivity in many ecosystems [6] [10] [11] [12].

Along with $\mathrm{C}$, the study of the dynamics of $\mathrm{N}$ is also essential in SOM studies, being one of the nutrients with more pronounced dynamics in the systems. Most of $\mathrm{N}$ lies in the organic part (90\%), where it represents a large reserve of the most readily available forms, such as nitrate and ammonia, which are released after mineralization of organic matter [13]. These mineral forms, although they account for a small part of total $\mathrm{N}$, are extremely important from a nutritional standpoint, since they represent forms readily absorbed by plants and microorganisms [14].

The objective of this study was to assess changes in levels of microbial $\mathrm{C}$ and mineral $\mathrm{N}$, nitrate $\mathrm{N}\left(\mathrm{NO}_{3}^{-}\right)$and ammonium $\left(\mathrm{NH}_{4}^{+}\right)$, and soil nutrients, in agroforestry systems and other land uses with different plant cover during the wet and dry seasons, in areas managed by indigenous communities and small farmers in the Alto Solimões region, Amazonas State, Brazil. 


\section{Material and Methods}

\subsection{Study Location}

The study took place in two indigenous communities, Guanabara II and Nova Aliança, in the municipality of Benjamin Constant, in the Alto Solimões region, in the northwestern portion of the state of Amazonas, Brazil (Figure 1), corresponding to a discontinuous surface of approximately $54,000 \mathrm{~m}^{2}$. These communities are made up of Brazilian Indians from the Ticuna ethnic group, and Peruvian Indians form the Cocama ethnic group. The Guanabara II community is located in an area on the right bank of the Solimões River, with coordinates of $4^{\circ} 24^{\prime} 21^{\prime \prime S}$ e $69^{\circ} 54^{\prime} 29^{\prime \prime} \mathrm{W}$, distant $13.8 \mathrm{~km}$ from the town of Benjamin Constant. The community of Nova Aliança is located $46.7 \mathrm{~km}$ from Benjamin Constant, and has the geographic coordinates $4^{\circ} 21^{\prime} 00^{\prime \prime} \mathrm{S}$ and $69^{\circ} 36^{\prime} 27^{\prime \prime} \mathrm{W}$. The climate, according to the Köppen classification, is Af, tropical wet or super-humid, with annual rainfall of $2562 \mathrm{~mm}$. The average annual temperature is around $25.7^{\circ} \mathrm{C}$, with the wet season (December-April) and one dry season (May to November) [15].

The study site consisted of six pilot areas called "windows" of about 9 ha each. The six windows are discontinuous areas, with 101 points marked $100 \mathrm{~m}$ apart (in some cases with $50 \mathrm{~m}$ apart), forming a sample grid representing major uses and ground cover [16] Windows 1 (J1) and 2 (J2) were located in the Guanabara II community, Windows 3 (J3), 4 (J4) and 5 (J5) in the Nova Aliança community, and Window 6 (J6) is southeast of Benjamin Constant about $2 \mathrm{~km}$ out of the town center [17].

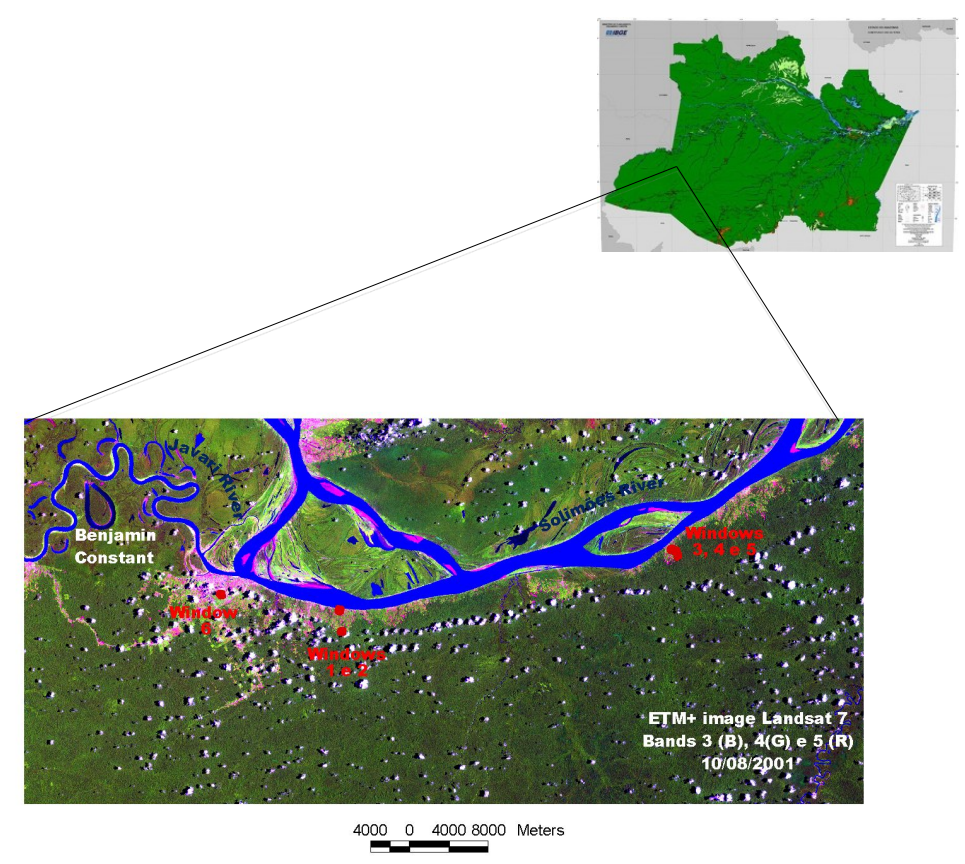

Figure 1. Location of Benjamin Constant County (window 6), Guanabara II community (windows 1 and 2) and the Nova Aliança community (windows 3, 4 and 5). 
The underlying geological material in the study area comes from the Solimões Formation, characterized by fluvial-lacustrine tertiary-quaternary sediments (red and gray mudstones, siltstones and sandstones, with layers of shells and lignite). The relief is relatively flat, with short and elongated knolls and softly undulating floodplains in other parts of the landscape. The Inceptisols are the dominant soil order [15].

\subsection{Land Use Systems Studied}

We studied six systems with the following land uses or cover: Primary Rainforest (FP); secondary forests in an advanced stage of recovery (FS) with more than 10 years under fallow; secondary forests in the early stages of recovery (CAP) with less than 10 years under fallow; Agroforestry (SAF) aged 15 to 30 years; plantations (RÇ), cultivated for 2 to 3 years, and 30 year old pastures (PAS). The characteristics of the vegetation of these systems are described below:

FP: Open Alluvial Rain Forest and Open Lowland Rain Forest. Individual Andiroba trees (Carapa guianensis) can be found in the region, along with Sumaúmeira (Kapok-Ceiba pentandra), Jatobazeiro (Hymenaea courbaril) and Seringueira (rubber) (Hevea brasiliensis);

FS: with speciessuch as Bacaba palm (Oenocarpus bacaba), peachpalm (Bactrisgasipaes), cedar (Cedrela odorata), Tucumã palm (Astrocarym aculeatum), and Sumaumeira;

CAP: Species of palmsuch as Tucumã (Astrocaryum vulgare) and Bacaba, Limorana (Chomelia sp.), Lacre (Vismia $s p$ ), Cecropia (Cecropia $s p$ ) andInga (Inga sp.);

SAF: Lemon (Citrus limonium), Coconut (Cocos nucifera), Bacaba, Peachpalm, Abiu (Pouteria caimito), Cupuaçu (Theobrama grandiflorum), Inga, Malay Apple (Eugenia malaccensis), Amazon Grape (Pouroma cecropiaefolia), Moriche Palm (Mauritia flexuosa), Cedar, Tucumã, Papaya (Carica papaya), and Genipap (Genipa americana) are cultivated;

RÇ: Cassava (Manihot esculenta) and banana (Musa sp.) are the most important produce cultivated. Besides these, other species such as pineapple (Ananas comosus) and Cupuaçu are also grown;

PAS: areas of pasture are restricted to the nearby town of Benjamin Constant where Imperial grass (Axonopus scoparius) was planted in the 1970s. Subsequently, Imperial grass pasture was replaced in some places with Brachiaria brizantha and Brachiaria humidicola, a native species called "Terra e Água" (from the floodplain) has also taken over.

Neither the indigenous or small farmers use purchased agricultural supplies or irrigation systems. They also do not use intense fire for clearing and soil preparation. The agroforestry areas are not raked or cleaned, and have a permanent litter layer. Systems of use and vegetative cover are distributed as follows: Window J1 consists of FP and CAP; J2 of CAP, SAF and RÇ; J3 and J4 of FP, CAP and RÇ; J5 of FS, CAP, SAF and RÇ; and J6 of FS and CAP. 


\subsection{Soil Analyses}

To assess the fertility of the soil, samples were collected at a depth of $0-5 \mathrm{~cm}$, at 101 points, in the wet season (May 2007). At each point of the windows, four single soil samples were collected within a radius of $3.0 \mathrm{~m}$, to form a composite sample. These samples were air-dried, loosened and sieved in $2 \mathrm{~mm}$ mesh to obtain fine air-dried soil (FADS) and submitted to chemical analysis. The following parameters were determined: $\mathrm{pH}$ in water $(1: 2.5 \mathrm{v} / \mathrm{v}) \mathrm{Ca}, \mathrm{Mg}$ and exchangeable $\mathrm{Al}$ by $\mathrm{KCl} 1 \mathrm{~mol} \cdot \mathrm{L}^{-1}$ extraction, $\mathrm{P}$ and available $\mathrm{K}$ by Mehlich-1 extractor, total $\mathrm{N}$ by the Kjedahl method, total organic $\mathrm{C}$ [18], Fe, $\mathrm{Zn}$ and available $\mathrm{Mn}$ through extraction by Mehlich-1, according to [19]. The clay content of soil samples was determined according to [20].

To estimate the microbial biomass carbon (MBC) and mineral $\mathrm{N}$, in the form of nitrate $\left(\mathrm{N}-\mathrm{NO}_{3}^{-}\right.$) and ammonium $\left(\mathrm{N}-\mathrm{NH}_{4}^{+}\right.$), samples were collected in two periods: the wet season (May 2007) and the dry season (October 2007). The soil samples were kept under refrigeration (approximately $4^{\circ} \mathrm{C}$ ) from collection until the time of analysis. The fumigation-extraction method was used to estimate microbial C [21]. The levels of mineral $\mathrm{N}$ in soils were determined according to [22]. The microbial quotient (qMIC) or MBC/total organic $\mathrm{C}$ was calculated according to [23].

\subsection{Statistical Analyses}

The relevant results for chemical composition, levels of $\mathrm{MBC}$, the levels of $\mathrm{N}$ $\mathrm{NH}_{4}^{+}$and of $\mathrm{N}-\mathrm{NO}_{3}^{-}$, in two seasons in the year, were subjected to analysis of variance (ANOVA), considering a completely random design, with three replications. The mean values of parameters in each system of land use were compared using the Tukey test at $1 \%$ and $5 \%$ levels of significance. Analysis was performed in the Systat 10 program for Windows [24].

The results were submitted to multivariate analysis using the ADE4 program [25]. The main component method was used to study the importance of the variables analyzed to correlate mean $\mathrm{MBC}, \mathrm{N}-\mathrm{NH}_{4}^{+}$e N- $\mathrm{NO}_{3}^{-}$levels in soil in different vegetation cover in each of the seasons, and then to correlate the microbiological attributes with fertility of the soil, $0-5 \mathrm{~cm}$ [26].

\section{Results and Discussion}

\subsection{Soil Fertility}

The conversion of FP in other systems of land use promotes change in some chemical properties of the soil (Table 1). The chemical composition of soils studied show that the levels of nutrients in the soil layer measured are above the average of most soils in Amazonia [27] [28]. The change in vegetative cover and management result in significant increases in $\mathrm{pH}$, levels of $\mathrm{P}, \mathrm{Ca}$ and $\mathrm{Mg}(\mathrm{P}<$ $0.05)$ and a decrease in the concentration of exchangeable Al. Higher $\mathrm{pH}$ levels were determined in the RÇ (5.14) and CAP (4.93) soils. Also the Al levels were significantly lower in these systems and in SAF, where the reduction in the level 
Table 1. Mean values of clay content, $\mathrm{pH}$, total organic carbon, total nitrogen, macronutrients $(\mathrm{P}, \mathrm{K})$ and available micronutrients $(\mathrm{Fe}, \mathrm{Zn}, \mathrm{Mn})$ contents and exchangeable cations in surface soil samples $(0-5 \mathrm{~cm})$ under different land use systems (LUS) in Benjamin Constant County, Upper Solimões River region, Amazonas state.

\begin{tabular}{ccccccccccc}
\hline LUS & Clay & $\mathrm{pH}$ & $\mathrm{Al}$ & $\mathrm{Ca}$ & $\mathrm{Mg}$ & $\mathrm{K}$ & $\mathrm{P}$ & $\mathrm{Zn}$ & $\mathrm{Mn}$ & $\mathrm{Fe}$ \\
\hline & $\mathrm{g} \mathrm{kg}^{-1}$ & & \multicolumn{6}{c}{$\mathrm{cmol}_{\mathrm{c}} \mathrm{kg}^{-1}$} \\
$\mathrm{FP}$ & 423 & $4.57 \mathrm{~b}$ & $1.86 \mathrm{a}$ & $7.60 \mathrm{ab}$ & $1.57 \mathrm{ab}$ & $0.19 \mathrm{~ns}$ & $5.22 \mathrm{ab}$ & $5.9 \mathrm{~ns}$ & $117 \mathrm{~ns}$ & $11.9 \mathrm{~b}$ \\
$\mathrm{FS}$ & 395 & $4.72 \mathrm{~b}$ & $1.87 \mathrm{a}$ & $7.56 \mathrm{ab}$ & $1.53 \mathrm{ab}$ & 0.21 & $5.65 \mathrm{ab}$ & 7.8 & 125 & $12.2 \mathrm{~b}$ \\
$\mathrm{CAP}$ & 361 & $4.93 \mathrm{a}$ & $0.77 \mathrm{~b}$ & $8.51 \mathrm{ab}$ & $1.70 \mathrm{a}$ & 0.25 & $5.40 \mathrm{ab}$ & 8.1 & 142 & $15.2 \mathrm{~b}$ \\
$\mathrm{SAF}$ & 390 & $4.79 \mathrm{~b}$ & $0.95 \mathrm{~b}$ & $8.76 \mathrm{ab}$ & $1.78 \mathrm{a}$ & 0.24 & $7.60 \mathrm{a}$ & 6.1 & 121 & $9.2 \mathrm{~b}$ \\
$\mathrm{RC}$ & 378 & $5.14 \mathrm{a}$ & $1.03 \mathrm{~b}$ & $9.78 \mathrm{a}$ & $1.75 \mathrm{a}$ & 0.22 & $5.00 \mathrm{ab}$ & 6.0 & 145 & $11.1 \mathrm{~b}$ \\
PAS & 326 & $4.74 \mathrm{~b}$ & $1.83 \mathrm{a}$ & $5.07 \mathrm{~b}$ & $0.99 \mathrm{~b}$ & 0.15 & $3.96 \mathrm{~b}$ & 4.1 & 74 & $30.3 \mathrm{a}$ \\
\hline
\end{tabular}

FP: primary rainforest; FS: secondary forests in an advanced stage of recovery; CAP: secondary forests in the early stages of recovery; SAF: agroforestry; RÇ: plantations; PAS: pasture. Means with same small letter in column not differ by Tukey $(\mathrm{P}<0.05)$ test; ns, not significantly different at the $P \leq 0.05$ level.

of Alwas around 50\%, which may be due to the neutralizing effect caused by the ashes from burning of the vegetation during clearing [29]. According to the criteria of [30], the $\mathrm{Ca}\left(>4 \mathrm{cmol}_{\mathrm{c}} \mathrm{kg}^{-1}\right)$ and $\mathrm{Mg}\left(>0.8 \mathrm{cmol}_{\mathrm{c}} \mathrm{kg}^{-1}\right)$ levels were high in all land use systems sampled. Ca levels, in relation to $\mathrm{FP}$, were $29 \%$ higher in RÇ and $11 \%$ in SAF and CAP; Mg increased $11 \%$ in the three systems. With regard to PAS, the levels of these elements decreased in $50 \%$ and $58 \%$, respectively, of $\mathrm{Ca}$ and $\mathrm{Mg}$ levels found in FP.

In general, $\mathrm{K}$ was considered medium $\left(0.15-0.30 \mathrm{cmol}_{\mathrm{c}} \mathrm{kg}^{-1}\right)$ [30], and no significant difference was detected between the levels of $\mathrm{K}$ in the six systems tested, however, in FP the $\mathrm{K}$ content $\left(0.19 \mathrm{cmol}_{\mathrm{c}} \mathrm{kg}^{-1}\right)$ was 26 and $16 \%$, respectively, lower than the values found in SAF $\left(0.24 \mathrm{cmol}_{\mathrm{c}} \mathrm{kg}^{-1}\right)$ and RÇ $\left(0.22 \mathrm{cmol}_{\mathrm{c}}\right.$ $\left.\mathrm{kg}^{-1}\right)$. Concentration of exchangeable $\mathrm{K}$ is generally low in the Amazon soils, and amounts below $0.30 \mathrm{cmol}_{\mathrm{c}} \mathrm{kg}^{-1}$ (a level regarded as appropriate) are typical in over $80 \%$ of the soils in the region [28]. The burning of primary forest biomass leads to rapid increases in soil $\mathrm{pH}$, exchangeable bases, effective cation exchange capacity and available P in surface soils [1] [31] [32] [33].

Only in SAF was the phosphorus $(\mathrm{P})$ content considered high $\left(>7.0 \mathrm{mg} \mathrm{kg}^{-1}\right)$ [30], differing significantly $(P<0.05)$ only from the PAS system $\left(3.96 \mathrm{mg} \mathrm{kg}^{-1}\right)$. However, P in SAF was $46 \%$ higher than FP $\left(5.22 \mathrm{mg} \mathrm{kg}^{-1}\right)$ in absolute values. [28] found a $\mathrm{P}$ content of less than $5.4 \mathrm{mg} \mathrm{kg}^{-1}$ in more than $80 \%$ of samples when assessing the availability of nutrients in 3340 soil samples analyzed ( 0 - 20 $\mathrm{cm}$ depth) throughout the State of Amazonas. The form and dynamics of $\mathrm{P}$ in soil may be significantly influenced by changes in land use, including changes in vegetative cover, biomass production and nutrient cycling [34]. A low P content detected in the PAS may be related to higher levels of $\mathrm{Fe}$ and $\mathrm{Al}$ in the soil, interfering in its availability to plants. In this study, higher levels of nutrients in SAF may be related to the management practiced by the indigenous farmers. This influence is mainly due to large amounts of household organic waste that is 
deposited in these areas due to proximity to homes [35]. [36] noted that indigenous agroforestry systems around dwellings in the savanna region of Roraima state resulted in an improvement in soil chemical properties over time, mainly due to management practices related to organic waste deposition and the burning of plant residues. Similar results were obtained by [37] in indigenous homegardens in the Central Amazon region.

With regard to micronutrients, Fe content in PAS $\left(30.38 \mathrm{mg} \mathrm{kg}^{-1}\right)$ was significantly higher $(\mathrm{P}<0.05)$ than in the other systems, reinforcing the idea that availability of $\mathrm{P}$ by burning can rapidly be reduced in these conditions; levels of $\mathrm{Zn}$ and Mn did not differ between systems (Table 1).

\subsection{Total Organic C, Microbial Biomass Carbon (MBC) and Soil Moisture}

The total organic C (TOC) content was considered high $\left(>26 \mathrm{~g} \mathrm{~kg}^{-1}\right)$ in all land use systems sampled [30] (Table 2). The high values of total organic-C content in the $0-5 \mathrm{~cm}$ layer reflect the accumulation of leaves, twigs, roots, and branches in the soil, and besides resulting in low $\mathrm{pH}$, help to slow the mineralization reaction, keeping the quantity of organic matter stable [28]. In general, replacement of FP by other systems of land use caused no significant changes in levels of total organic C (TOC) in the $0-5 \mathrm{~cm}$ layer, except that PAS had the lowest TOC content ( $\left.39.44 \mathrm{~g} \mathrm{~kg}^{-1}\right)$, differing from the other systems, which ranged from 45.61 to $53.68 \mathrm{~g} \mathrm{~kg}^{-1}$. In an Oxisol from Western Amazonia, [1] also observed that the organic $\mathrm{C}$ was significantly higher in areas with forest and agroforestry systems than in pastures.

Higher values of $\mathrm{MBC}$ were observed in the wet season, with levels ranging from $365.5 \mu \mathrm{g} \mathrm{g}^{-1}$ in the RÇ, and $599.3 \mu \mathrm{g} \mathrm{g}^{-1}$, in FP (Table 2). In the wet season,

Table 2. Total organic carbon (TOC), moisture, microbial biomass carbon (MBC) content and microbial quotient (qMIC) of surface soil samples $(0-5 \mathrm{~cm})$ under different land use systems (LUS) in Benjamin Constant County, Upper Solimões River region, Amazonas state.

\begin{tabular}{cccccccc}
\hline \multirow{2}{*}{ LUS } & TOC & \multicolumn{3}{c}{ Wet season } & \multicolumn{3}{c}{ Dry season } \\
\cline { 3 - 7 } & & Moisture & MBC & $q$ MIC & Moisture & MBC & $q$ MIC \\
\hline & $\mathrm{g} \mathrm{kg}^{-1}$ & $\%$ & $\mu \mathrm{g} \mathrm{g}^{-1}$ & $\%$ & $\%$ & $\mu \mathrm{g} \mathrm{g}^{-1}$ & $\%$ \\
FP & $51.61 \mathrm{a}$ & $63 \mathrm{~ns}$ & $599.3 \mathrm{nsA}$ & $1.16 \mathrm{aA}$ & $41 \mathrm{~ns}$ & $239.4 \mathrm{bB}$ & $0.46 \mathrm{nsB}$ \\
FS & $45.36 \mathrm{a}$ & 58 & $484.3 \mathrm{~A}$ & $1.06 \mathrm{aA}$ & 33 & $241.6 \mathrm{bB}$ & $0.53 \mathrm{~B}$ \\
CAP & $52.29 \mathrm{a}$ & 57 & $488.6 \mathrm{~A}$ & $0.93 \mathrm{abA}$ & 36 & $242.1 \mathrm{bB}$ & $0.46 \mathrm{~B}$ \\
SAF & $45.61 \mathrm{a}$ & 55 & $377.6 \mathrm{NS}$ & $0.83 \mathrm{abNS}$ & 36 & $365.3 \mathrm{aNS}$ & $0.80 \mathrm{NS}$ \\
RÇ & $53.68 \mathrm{a}$ & 56 & $365.6 \mathrm{~A}$ & $0.68 \mathrm{bA}$ & 41 & $206.1 \mathrm{bB}$ & $0.38 \mathrm{~B}$ \\
PAS & $39.44 \mathrm{~b}$ & 55 & $528.8 \mathrm{~A}$ & $1.32 \mathrm{aA}$ & 43 & $193.3 \mathrm{bB}$ & $0.49 \mathrm{~B}$ \\
\hline
\end{tabular}

FP: primary rainforest; FS: secondary forests in an advanced stage of recovery; CAP: secondary forests in the early stages of recovery; SAF: agroforestry; RÇ: plantations; PAS: pasture. Means with same single letter in column and same capital letter within season do not differ by Tukey $(\mathrm{P}<0.05)$ test; ns, not significantly different at the $P \leq 0.05$ level. 
the MBC contents were higher in FP and PAS samples. This could be related to the fact that grasses of the genus Brachiaria in PAS have the potential of adding large amounts of organic $\mathrm{C}$ and $\mathrm{N}$ to the soil, due to continuous root activity and litter deposition [33]. Similar results have been obtained in other studies in Amazonia [33] [38]. Although not differing significantly from each other, the conversion of FP in RÇ and/or SAF promoted a reduction of approximately $40 \%$ in the MBC content. This result probably reflects the adverse effect of burning on this soil quality indicator, confirming other studies that demonstrated the strong and lasting effect of fire on soil microbial communities [39] [40]. The differences in the MBC values between seasons emphasizes the dependence of the microbial community on soil moisture [41] [42] [43], although no significant difference was observed between the moisture content of soil sampled in different systems, in both seasons (Table 2). The average reduction in moisture content in the dry season was $33 \%$ in the systems studied.

With the change in soil moisture, changes in microbial biomass between the different systems are more pronounced. In the wet season there is no statistical difference between $M B C$ values, however, in the dry season, the values found in SAF were significantly higher than the other systems. In SAF, the carbon retained in local microbiota was similar in the two seasons, although soil moisture is 35\% lower; in PAS, the reduction in MBC between seasons was 63\%. This sharp decline is probably due to the low level of soil fertility under pasture, as previously mentioned (Table 1). [44] [45] observed lower activities of soil microorganisms due to seasonal reduction in soil moisture content of pasture.

The microbial quotient (qMIC), which expresses how much of the soil organic carbon is held in microbial biomass, varied between systems and seasons (Table 2). A lower capacity to retain $\mathrm{C}$ in microorganisms occurred in $\mathrm{RÇ}(0.68 \%)$ and PAS $(0.38 \%)$, respectively, in the wet and dry seasons. The results found are lower than those reported by [46] for tropical forest soils (1.5\% to $5.3 \%)$, for temperate forests (1.8\% to $2.9 \%$ ) [21], and similar to those obtained by [33], who found that variation of $0.2 \%$ to $2.3 \%$ in soils under primary forest, scrub and grassland in the southwestern region of Amazonia. Microbial quotient values below $0.5 \%$ suggest that the microbial biomass is being subjected to some form of stress (nutrient deficiency, acidity, high levels of Al), thereby affecting the ability to use C, thus limiting microbial activity [47] [48]. According to [49], among the abiotic factors, moisture is one that exerts the greatest influence on soil microbial populations and nutrient dynamics.

\subsection{Total-N, Mineral-N, Nitrate $\left(\mathrm{NO}_{3}^{-}\right)$and Ammonium $\left(\mathrm{NH}_{4}^{+}\right)$}

Total Nitrogen $(\mathrm{N})$ content did not differ between the systems assessed, with the exception of PAS (Table 3). Compared to FP, the levels of total $\mathrm{N}$ indicated that the establishment of pastures promoted a significant decrease $(\mathrm{P}<0.05)$ in stocks in the soil. This decrease is mainly due to the reduction in the amount of organic matter in the surface layer. In addition, the decrease in total $\mathrm{N}$ content 
Table 3. Total nitrogen $(\mathrm{Nt})$, mineral nitrogen ( $\mathrm{N}$-mineral), nitrate $\left(\mathrm{N}-\mathrm{NO}_{3}^{-}\right)$and ammonium $\left(\mathrm{N}-\mathrm{NH}_{4}^{+}\right)$forms of surface soil samples $(0-5 \mathrm{~cm})$ under different land use systems (LUS) in Benjamin Constant County, Upper Solimões River region, Amazonas state.

\begin{tabular}{cccccccc}
\hline \multirow{2}{*}{ LUS } & $\mathrm{Nt}$ & \multicolumn{3}{c}{ Wet season } & \multicolumn{3}{c}{ Dry season } \\
\cline { 3 - 7 } & & NMineral & $\mathrm{NH}_{4}^{+}$ & $\mathrm{NO}_{3}^{-}$ & NMineral & $\mathrm{NH}_{4}^{+}$ & $\mathrm{NO}^{-}$ \\
\hline & $\mathrm{g} \mathrm{kg}^{-1}$ & & $\mu \mathrm{g} \mathrm{g}^{-1}$ & & & $\mu \mathrm{g} \mathrm{g}^{-1}$ & \\
\hline FP & $3.43 \mathrm{a}$ & 11.55 & $7.53 \mathrm{abNS}$ & $4.02 \mathrm{abNS}$ & 13.32 & $9.86 \mathrm{bNS}$ & $3.46 \mathrm{abNS}$ \\
$\mathrm{FS}$ & $3.33 \mathrm{a}$ & 12.41 & $8.39 \mathrm{abB}$ & $6.74 \mathrm{aA}$ & 17.15 & $14.74 \mathrm{abA}$ & $2.40 \mathrm{abB}$ \\
$\mathrm{CAP}$ & $3.46 \mathrm{a}$ & 15.49 & $11.98 \mathrm{aB}$ & $3.51 \mathrm{abA}$ & 20.20 & $18.38 \mathrm{aA}$ & $1.82 \mathrm{bB}$ \\
SAF & $3.22 \mathrm{a}$ & 15.66 & $12.32 \mathrm{aNS}$ & $3.34 \mathrm{abNS}$ & 17.38 & $15.28 \mathrm{abNS}$ & $2.10 \mathrm{abNS}$ \\
RÇ & $3.42 \mathrm{a}$ & 13.64 & $6.31 \mathrm{bB}$ & $7.33 \mathrm{aA}$ & 22.64 & $18.33 \mathrm{aA}$ & $4.31 \mathrm{aB}$ \\
PAS & $2.86 \mathrm{~b}$ & 11.02 & $10.25 \mathrm{aNS}$ & $0.77 \mathrm{bB}$ & 13.82 & $12.12 \mathrm{abNS}$ & $1.71 \mathrm{bA}$ \\
\hline
\end{tabular}

FP: primary rainforest; FS: secondary forests in an advanced stage of recovery; CAP: secondary forests in the early stages of recovery; SAF: agroforestry; RÇ: plantations; PAS: pasture. Means with same single letter in column and same capital letter within season not differ by Tukey $(\mathrm{P}<0.05)$ test; ns, not significantly different at the $P \leq 0.05$ level.

may also be associated with changes in soil structure, which affects biological activity [50]. Studies show that soil texture has a great influence on the concentration of $\mathrm{N}$, water retention, the availability of nutrients and maintenance of $\mathrm{C}$ in soils, especially those that are highly weathered [13] [51]. In comparing forest soils with different clay contents in the Amazonian region, greater cycling and $\mathrm{N}$ retention were observed in the more clayey soil [52]. In this context, the lower clay content of soil in PAS (Table 1) may be influencing the $\mathrm{N}$ content. The general trend in tropical soils after the forest has been converted into pasture has been an increase in the sand and a decrease in the clay content [53].

Mineral $\mathrm{N}$ levels, defined as the sum of nitrate $\left(\mathrm{NO}_{3}^{-}\right)$and ammonium $\left(\mathrm{NH}_{4}^{+}\right)$, were higher during the dry season in all systems (Table 3). The extent of values found is in line with other authors [54] [55] who also found levels of mineral $\mathrm{N}$ to be higher during the dry season in Amazon soils. Between the two forms, there was a predominance of the $\mathrm{N}-\mathrm{NH}_{4}^{+}$form in all systems in the two seasons, but with an increase in the dry season. Similar results were found by [46] [54] who found higher concentrations of $\mathrm{N}^{-} \mathrm{NH}_{4}^{+}$in comparison to N- $\mathrm{NO}_{3}^{-}$in various vegetation covers and land use systems. Higher concentrations of $\mathrm{N}$ $\mathrm{NH}_{4}^{+}$suggest nitrification inhibition in soil of all systems studied, regardless of the season. The nitrification inhibition has important implications in $\mathrm{N}$ cycling and conservation in ecosystems. The availability of these two nitrogen forms depends on physical and chemical factors which regulate the ammonification and nitrification processes. In acid soils of Amazonia, nitrification can be reduced by low $\mathrm{pH}$, thus $\mathrm{N}-\mathrm{NH}_{4}^{+}$is the main source of $\mathrm{N}$ to plants [56]. With respect to systems, the concentration of $\mathrm{N}-\mathrm{NH}_{4}^{+}$was significantly higher in CAP, SAF and PAS, in both seasons (Table 3). Concentrations of $\mathrm{N}-\mathrm{NH}_{4}^{+}$in $\mathrm{RC}$ stand out for having tripled in the dry season, which was not observed in other systems. In SAF, there was no statistical difference between the levels of $\mathrm{N}-\mathrm{NH}_{4}^{+}$, 
in two seasons, however, in the dry season, the concentration of $\mathrm{N}^{-\mathrm{NH}_{4}^{+}}$was $24 \%$ higher.

Levels of N- $\mathrm{NO}_{3}^{-}$in $\mathrm{FP}$ and SAF did not differ between seasons, however, for other systems, the difference was significant $(p<0.05)$, especially for RÇ and

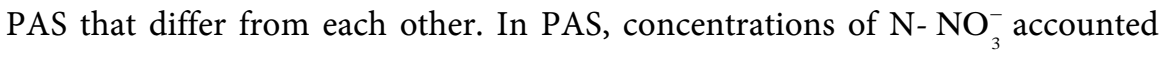
for $10 \%$ of the value obtained in RÇ, in the wet season, and $40 \%$ in the dry season, but it was the only system where concentrations of $\mathrm{N}^{-\mathrm{NO}_{3}^{-}}$increased with a reduction in moisture content of the soil. Results indicate that changes in land use can drive the predominance of specific groups of soil microorganisms, or induce significant loss of diversity as a whole, reflecting variations in concentrations of $\mathrm{NO}_{3}^{-}$and $\mathrm{NH}_{4}^{+}$in managed systems [33].

\subsection{Principal Component Analysis (PCA)}

The results presented in Figure 2(a), Figure 2(b) mainly separate systems of land use variables as a function of $\mathrm{MBC}$ and $\mathrm{N}-\mathrm{NO}_{3}^{-}$and $\mathrm{N}-\mathrm{NH}_{4}^{+}$during the wet season. The sum of the first two factors explains $94 \%$ of total variables. The first factor, F1, explains 58\% and the levels of $\mathrm{MBC}$ and $\mathrm{N}-\mathrm{NH}_{4}^{+}$are more correlated to systems CAP, SAF, PAS and FP, while the RC and FS systems are related to higher levels of $\mathrm{N}^{-\mathrm{NO}_{3}^{-}}$. The second factor, $\mathrm{F} 2$, explains $36 \%$ of the total variability, separating the RÇ, CAP and SAF systems (with the levels of $\mathrm{N}-\mathrm{NO}_{3}^{-}$ e N- $\mathrm{NH}_{4}^{+}$) of FP, FS and PAS (with levels of MBC). Figure 2(a), Figure 2(b) also shows the size of the vector (greatest distance from the center) where microorganisms accumulate in soil under FP during the wet season, the nitrification process in $\mathrm{RÇ}$ and the intense ammonification process being more pronounced in SAF.

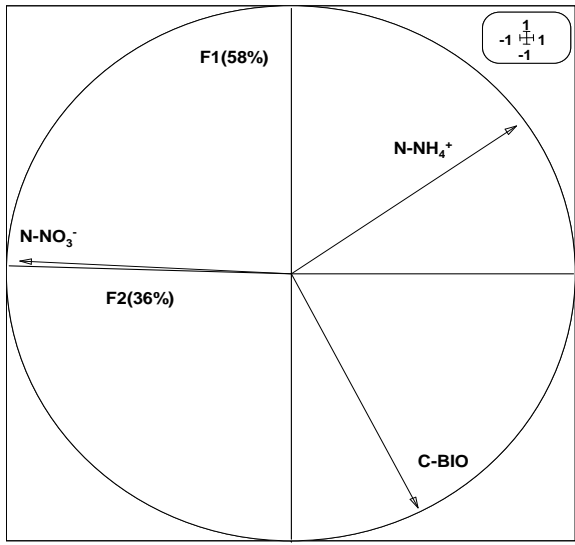

(a)

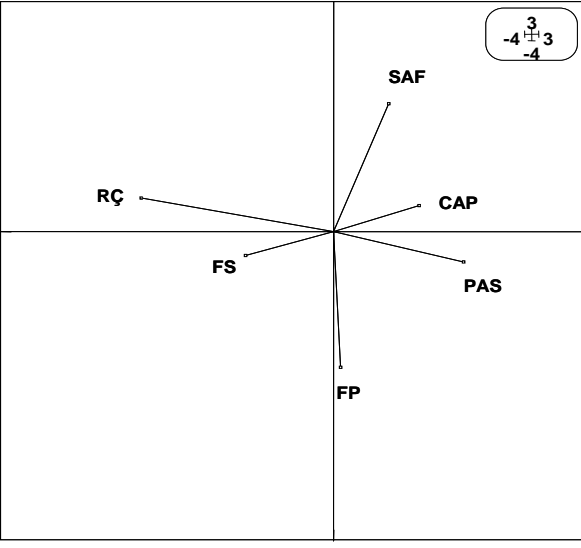

(b)

Figure 2. (a) Microbial biomass carbon correlation $(\mathrm{MBC}=\mathrm{C}-\mathrm{Bio})$ between $\mathrm{N}-\mathrm{NH}_{4}^{+}$ and $\mathrm{N}-\mathrm{NO}_{3}^{-}$and the soil chemical attributes, of Amazon soil samples $(0-5 \mathrm{~cm})$ collected in the wet season; (b) Principal component analysis among land use (FP: primary rainforest; FS: secondary forests in an advanced stage of recovery; CAP: secondary forests in the early stages of recovery; SAF: agroforestry; RÇ: plantations; PAS: pasture) correlated with soil chemical attributes, $\mathrm{MBC}, \mathrm{N}-\mathrm{NH}_{4}^{+}$and $\mathrm{N}-\mathrm{NO}_{3}^{-}$, of Amazon soil samples (0 - 5 $\mathrm{cm}$ ) collected in the wet season. 
In the dry season, $76 \%$ of the total variability was explained by the first two factors (Figure 3(a), Figure 3(b)). The F1 axis explains $42 \%$ content of $\mathrm{C}$ held by microbial biomass and the process of ammonification being more intense in SAF, CAP and PAS. On the other hand, the nitrification process occurred more intensely in RÇ, a little less in FP and FS with an intermediate position. F2 explains $34 \%$ of this correlation, separating the SAF, CAP and RÇ with the processes of ammonification, nitrification and immobilization of MBC. Nitrification remains intense in $\mathrm{RC}$ and ammonification in SAF, occurring in the wet season, with only a change in the behavior of microorganisms during the dry season, accumulated in SAF.

The results presented in Figure 4(a), Figure 4(b) and Figure 5(a), Figure 5(b) express the relationship between systems and soil fertility, the level of MBC and concentrations of $\mathrm{N}^{-\mathrm{NO}_{3}^{-}}$and $\mathrm{N}-\mathrm{NH}_{4}^{+}$in the two seasons. Factors 1 and 2 , respectively, explain $59 \%$ and $17 \%$ of the variability of $\mathrm{MBC}$ of soil and soil fertility in each of the systems studied, both in the wet season and in dry season. Regardless of the season, SAFs, RÇ and PAS differ from the origin, separating systems FP, FS and CAP.

In general, the contents of $\mathrm{NO}_{3}^{-}$, total $\mathrm{C}$, total $\mathrm{N}$ and $\mathrm{Ca}$ are related in two seasons with RÇ. Levels of $\mathrm{P}, \mathrm{K}$ and $\mathrm{Mg}$ are correlated in two seasons with SAF and PAS correlates with high levels of Fe (Table 1). FP correlates in two seasons with high $\mathrm{Al}$ values. As seen in the correlations between the various systems and the contents of $\mathrm{MBC}$ and the concentrations of $\mathrm{NO}_{3}^{-}$e $\mathrm{NH}_{4}^{+}$(Table 4 and Table 5) MBC is correlated with FP, in the wet season, and, the dry season, correlates with SAF.

This suggests that in the wet season, regardless of the acidity and higher levels of $\mathrm{Al}$ in these soils, microorganisms present showed increased activity in

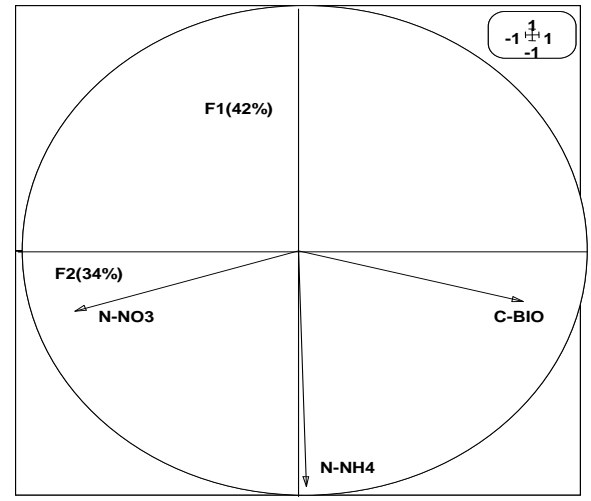

(a)

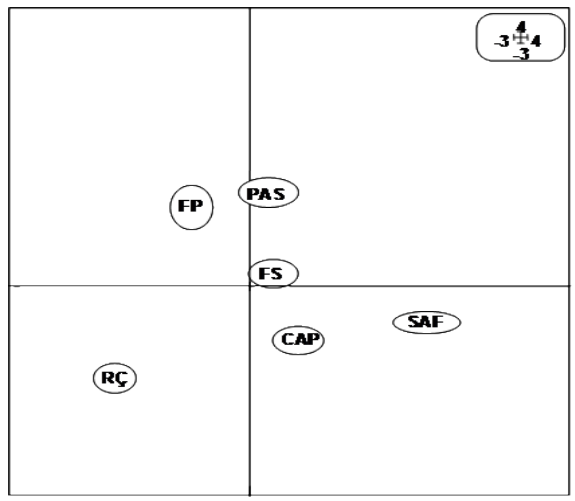

(b)

Figure 3. (a) Microbial biomass carbon $(\mathrm{MBC}=\mathrm{C}-\mathrm{Bio})$ correlation between $\mathrm{N}-\mathrm{NH}_{4}^{+}$ and $\mathrm{N}-\mathrm{NO}_{3}^{-}$and the soil chemical attributes, of Amazon soil samples $(0-5 \mathrm{~cm})$ collected in the dry season; (b) Principal component analysis among land use (FP: primary rainforest; FS: secondary forests in an advanced stage of recovery; CAP: secondary forests in the early stages of recovery; SAF: agroforestry; RÇ: plantations; PAS: pasture) correlated with soil chemical attributes, $\mathrm{MBC}, \mathrm{N}-\mathrm{NH}_{4}^{+}$and $\mathrm{N}-\mathrm{NO}_{3}^{-}$, of Amazon soil samples (0 - 5 $\mathrm{cm}$ ) collected in the dry season. 


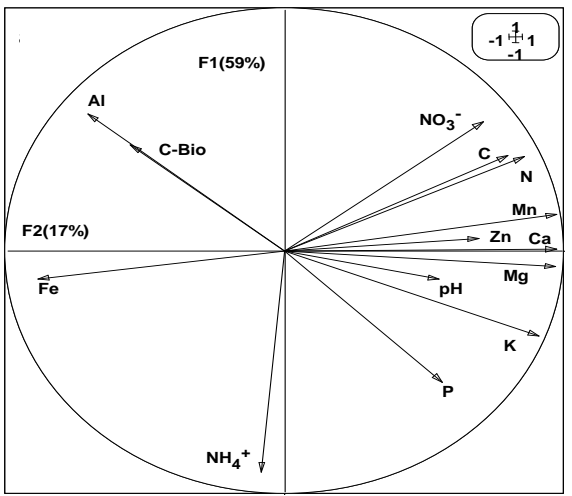

(a)

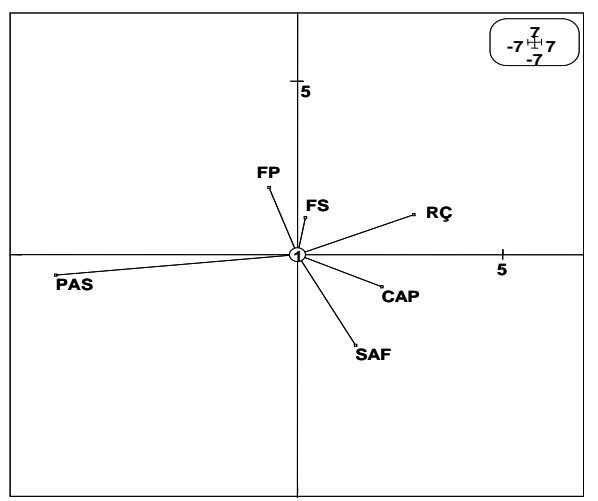

(b)

Figure 4. (a) Microbial biomass carbon $(\mathrm{MBC}=\mathrm{C}-\mathrm{Bio})$ correlation between $\mathrm{N}-\mathrm{NH}_{4}^{+}$ and $\mathrm{N}-\mathrm{NO}_{3}^{-}$and the soil chemical attributes, of Amazon soil samples $(0-5 \mathrm{~cm})$ collected in the wet season; (b) Principal component analysis among land use (FP: primary rainforest; FS: secondary forests in an advanced stage of recovery; CAP: secondary forests in the early stages of recovery; SAF: agroforestry; RÇ: plantations; PAS: pasture) correlated with soil chemical attributes, $\mathrm{MBC}, \mathrm{N}-\mathrm{NH}_{4}^{+}$and $\mathrm{N}-\mathrm{NO}_{3}^{-}$, of Amazon soil samples (0 - 5 $\mathrm{cm})$ collected in the wet season.

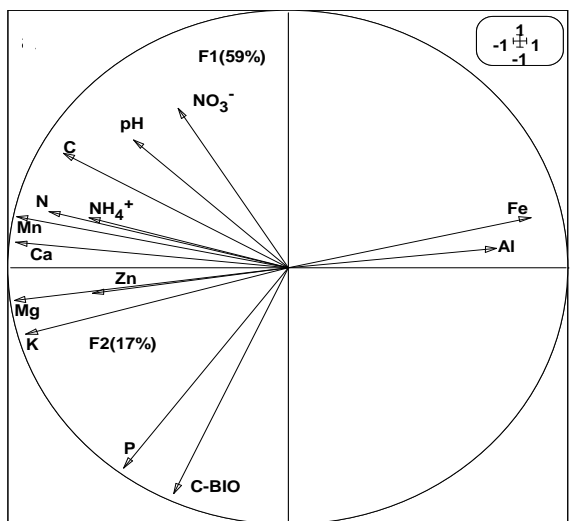

(a)

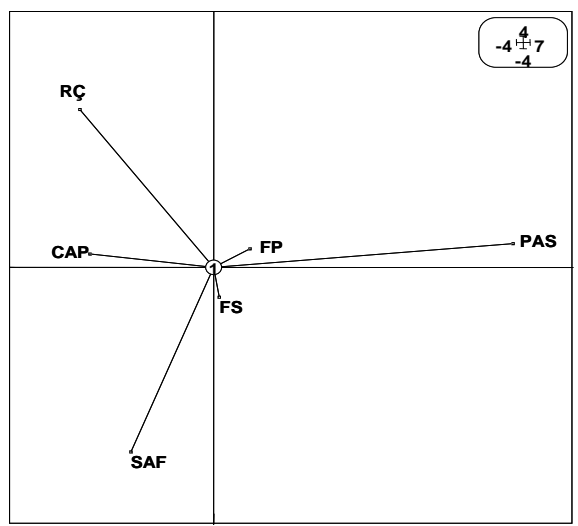

(b)

Figure 5. (a) Microbial biomass carbon $(\mathrm{MBC}=\mathrm{C}-\mathrm{Bio})$ correlation between $\mathrm{N}-\mathrm{NH}_{4}^{+}$ and $\mathrm{N}-\mathrm{NO}_{3}^{-}$and the soil chemical attributes, of Amazon soil samples $(0-5 \mathrm{~cm})$ collected in the dry season; (b) Principal component analysis among land use (FP: primary rainforest; FS: secondary forests in an advanced stage of recovery; CAP: secondary forests in the early stages of recovery; SAF: agroforestry; RÇ: plantations; PAS: pasture) correlated with soil chemical attributes, $\mathrm{MBC}, \mathrm{N}-\mathrm{NH}_{4}^{+}$and $\mathrm{N}_{-} \mathrm{NO}_{3}^{-}$, of Amazon soil samples (0 - 5 $\mathrm{cm})$ collected in the dry season.

soils under FP. On the other hand, when there is a reduction in soil moisture content in the system, in the dry season, the microorganisms do not withstand high levels of $\mathrm{Al}$ associated with low fertility, reducing their activity; while in more fertile soils (higher levels of $\mathrm{P}, \mathrm{K}, \mathrm{Ca}, \mathrm{Mg}$ ), that are less acidic and have lower A1 values, as found in soils with SAF (Table 1), an increased activity of microorganisms in the soil is suggested. From the data of the correlation matrix generated from ACP, there is high positive correlation between the contents of $\mathrm{MBC}$ and the levels of $\mathrm{P}, \mathrm{K}$ and $\mathrm{Mg}$ during the dry season. 
Table 4. Correlation matrix between soil chemical attributes, $\mathrm{N}-\mathrm{NH}_{4}^{+}, \mathrm{N}-\mathrm{NO}_{3}^{-}$and microbial biomass carbon $(\mathrm{MBC})$, in samples collected from the surface layer $(0-5 \mathrm{~cm})$, in the wet season.

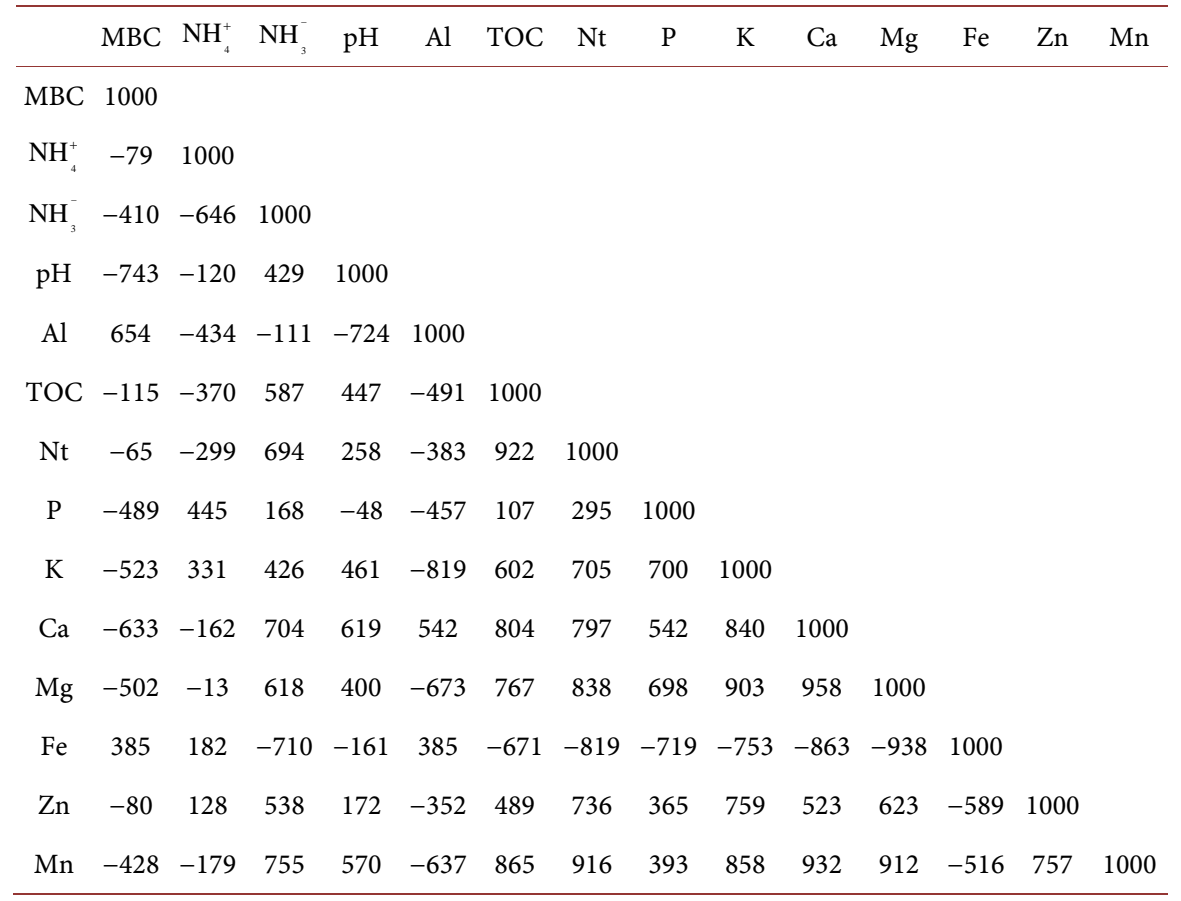

Table 5. Correlation matrix between soil chemical attributes, $\mathrm{N}-\mathrm{NH}_{4}^{+}, \mathrm{N}_{-} \mathrm{NO}_{3}^{-}$and microbial biomass carbon (MBC), in samples collected from the surface layer $(0-5 \mathrm{~cm})$, in the dry season.

\begin{tabular}{ccccccccccccccc}
\hline & $\mathrm{MBC}^{2}$ & $\mathrm{NH}_{4}^{+}$ & $\mathrm{NH}_{3}^{-}$ & $\mathrm{pH}$ & $\mathrm{Al}$ & $\mathrm{TOC}$ & $\mathrm{Nt}$ & $\mathrm{P}$ & $\mathrm{K}$ & $\mathrm{Ca}$ & $\mathrm{Mg}$ & $\mathrm{Fe}$ & $\mathrm{Zn}$ & $\mathrm{Mn}$ \\
\hline $\mathrm{MBC}$ & 1000 & & & & & & & & & & & & & \\
$\mathrm{NH}_{4}^{+}$ & 74 & 1000 & & & & & & & & & & & & \\
$\mathrm{NH}_{3}^{-}$ & -260 & 65 & 1000 & & & & & & & & & & & \\
$\mathrm{pH}$ & -173 & 890 & 346 & 1000 & & & & & & & & & & \\
$\mathrm{Al}$ & -403 & -823 & 3 & -724 & 1000 & & & & & & & & & \\
$\mathrm{TOC}$ & -54 & 428 & 664 & 447 & -491 & 1000 & & & & & & & & \\
$\mathrm{Nt}$ & 107 & 390 & 530 & 258 & -383 & 922 & 1000 & & & & & & & \\
$\mathrm{P}$ & 969 & 217 & -114 & -48 & -457 & 107 & 295 & 1000 & & & & & & \\
$\mathrm{~K}$ & 569 & 737 & 39 & 461 & -819 & 602 & 705 & 700 & 1000 & & & & & \\
$\mathrm{Ca}$ & 363 & 676 & 561 & 619 & -715 & 804 & 797 & 542 & 840 & 1000 & & & & \\
$\mathrm{Mg}$ & 539 & 553 & 416 & 400 & -673 & 767 & 838 & 698 & 903 & 958 & 1000 & & & \\
$\mathrm{Fe}$ & -552 & 316 & -494 & -161 & 385 & -671 & -819 & -719 & -753 & -863 & -938 & 1000 & & \\
$\mathrm{Zn}$ & 195 & 540 & -71 & 172 & -352 & 489 & 736 & 365 & 759 & 523 & 623 & -589 & 1000 & \\
$\mathrm{Mn}$ & 186 & 708 & 473 & 570 & -637 & 865 & 916 & 393 & 858 & 932 & 912 & -516 & 757 & 1000 \\
\hline
\end{tabular}

\section{Conclusions}

In the Alto Solimões region of Amazonas, Brazil, conversion of primary rainfor- 
est to other systems of land use promotes changes in some soil chemical properties, resulting in significant increases in $\mathrm{pH}$, concentration of $\mathrm{P}, \mathrm{Ca}$ and $\mathrm{Mg}$ and decrease in the concentration of $\mathrm{Al}$, especially in agroforestry systems.

Levels of total organic carbon and total nitrogen differed significantly only in soils under pasture.

Changes in microbial carbon content were found between systems and between seasons, while levels of microbial carbon in agroforestry systems did not differ between seasons.

Mineral $\mathrm{N}$ in the form of $\mathrm{N}-\mathrm{NH}_{4}^{+}$was predominant in both seasons, in all systems studied, with higher levels in the dry season.

The results presented depict a positive effect over time of management practiced by the indigenous farmers on soil chemical properties, microbial carbon and mineral nitrogen in the $0-5 \mathrm{~cm}$ deep layer of an Inceptisol, independent of soil moisture, reflecting positively on soil quality.

\section{Acknowledgements}

This manuscript presents part of the findings of the international project "Conservation and Management of Below-Ground Biodiversity" (CSM-BGBD) implemented in seven tropical countries-Brazil, Cote d'Ivoire, India, Indonesia, Kenya, Mexico, and Uganda. This project is coordinated by the Tropical Soil Biology and Fertility Institute of CIAT (TSBF-CIAT) with co-financing from the Global Environmental Facility (GEF), and implementation support from the United Nations Environment Program (UNEP). Views expressed in this publication are those of their authors and do not necessary reflect hose of the authors' organization, the United Nations Environment Programme and the Global Environmental Facility. The Brazilian component of the CSM-BGBD project is called BiosBrasil and is coordinated by UFLA (http://www.biosbrasil.ufla.br).

\section{References}

[1] Alfaia, S.S., Ribeiro, G.A., Nobre, A.N., Luizão, R.C. and Luizão, F.J. (2004) Evaluation of Soil Fertility in Smallholder Agroforestry Systems and Pastures in Western Amazonia. Agriculture, Ecosystems and Environment, 102, 409-414. https://doi.org/10.1016/j.agee.2003.08.011

[2] Joslin, A.H., Markewitz, D., Morris, L.A., Oliveira, F.A., Figueiredo, R.O. and Kato, O.R. (2011) Five Native Tree Species and Manioc under Slash-and-Mulch Agroforestry in the Eastern Amazon of Brazil: Plant Growth and Soil Response. Agroforestry Systems, 81, 1-14. https://doi.org/10.1007/s10457-010-9356-1

[3] Schloter, M., Dilly, O. and Munch, J.C. (2003) Indicators for Evaluating Soil Quality. Agriculture, Ecosystems and Environment, 98, 255-262.

https://doi.org/10.1016/S0167-8809(03)00085-9

[4] Swift, M.J. and Woomer, P.L. (1993) Organic Matter and the Sustainability of Agricultural Systems: Definition and Measurement. In: Mulongoy, K. and Merckx, R. Eds., Soil Organic Matter Dynamics and Sustainability of Tropical Agriculture, IITA, Leuven, 3-18.

[5] Bastida, F., Zsolnay, A., Hernández, T. and García, C. (2008) Past, Present and Future of Soil Quality Indices: A Biological Perspective. Geoderma, 147, 159-171. 
https://doi.org/10.1016/j.geoderma.2008.08.007

[6] Gama-Rodrigues, E.F., Barros, N.F., Gama-Rodrigues, A.C. and Santos, G.A. (2005) Nitrogênio, carbono e atividade da biomassa microbiana do solo em plantações de eucalipto. Revista Brasileira de Ciência do Solo, 29, 893-902. https://doi.org/10.1590/S0100-06832005000600007

[7] Jenkinson, D.S. and Ladd, J.M. (1981) Microbial Biomass in Soil: Measurement and Turnover. In: Paul, E.A. and Ladd, J.M., Eds., Soil Biochemistry, Dekker, New York, 415-471.

[8] Smith, J.L. and Paul, E.A. (1990) The Significance of Soil Microbial Biomass Estimations. In: Bollag, J. and Stotzky, J.D.G., Eds., SOIL Biochemistry, Dekker, New York, 357-396.

[9] Moreira, F.M.S. and Siqueira, J.O. ( 2006) Microbiologia e bioquímica do solo, Universidade Federal de Lavras, Lavras, Minas Gerais.

[10] Dinesh, R., Chaudhuri, S.G., Ganeshamurthy, A.N. and Dey, C. (2003) Changes in Soil Microbial Indices and Their Relationships Following Deforestation and Cultivation in Wet Tropical Forest. Applied Soil Ecology, 24, 17-23. https://doi.org/10.1016/S0929-1393(03)00070-2

[11] Fernandes, F.A., Fernandes, A.H. and Crispim, S.M.A. (2007) Biomassa microbiana e conteúdos de carbono e nitrogênio do solo em áreas de pastagem nativa sujeita à queimada, Pantanal Mato-Grossense. Boletim de Pesquisa e Desenvolvimento, 73. Embrapa Pantanal, Corumbá. http://www.cpap.embrapa.br/publicacoes/online/BP73.pdf

[12] Silva, R.R., Silva, M.L.N., Cardoso, E.L., Moreira, F.M.S., Curi, N. and Alovisi, A.M.T. (2010) Biomassa e atividade microbiana em solo sob diferentes sistemas de manejo na região fisiográfica Campos das Vertentes-MG. Revista Brasileira de Ciência do Solo, 34, 1584-1592. https://doi.org/10.1590/S0100-06832010000500011

[13] Luizão, R.C.C., Luizão, F.J., Paiva, R.Q., Monteiro, T.F., Sousa, L.S. and Kruijt, B. (2004) Variation of Carbon and Nitrogen Cycling Processes along a Topographic Gradient in a Central Amazonian Forest. Global Change Biology, 10, 592-600. https://doi.org/10.1111/j.1529-8817.2003.00757.x

[14] Cleveland, C.C., Townsend, A.R., Constance, B.C., Ley, R.E. and Schmidt, S.K. (2004) Soil Microbial Dynamics in Costa Rica: Seasonal and Biogeochemical Constraints. Biotropica, 36, 184-195. https://doi.org/10.1111/j.1744-7429.2004.tb00311.x

[15] Coelho, M.R., Fidalgo, E.C.C., Araújo, F.O., Santos, H.G., Santos, M.L., Pérez, D.V. and Moreira, F.M.S. (2005) Solos das áreas-piloto do Projeto GEF BIOS (Conservation and Sustainable Management of Below-Ground Biodiversity: Phase I), Município de Benjamin Constant, Estado do Amazonas. Embrapa Solos, Rio de Janeiro. Boletim de Pesquisa e Desenvolvimento, 67.

[16] Biosbrasil (2005) http://www.biosbrasil.ufla.br

[17] Fidalgo, E.C.C., Coelho, M.R., Araújo, F.O., Moreira, F.M.S., Santos, H.G., Santos, M.L. and Huising, J. (2005) Levantamento do Uso e Cobertura da Terra de Seis Áreas Amostrais Relacionadas ao Projeto BiosBrasil (Conservation and Sustainable Management of Below-Ground Biodiversity: Phase I), Município de Benjamin Constant (AM). Embrapa Solos, Rio de Janeiro. Boletim de Pesquisa e Desenvolvimento, 71 .

[18] Yeomans, J.C. and Bremner, J.M. (1988) A Rapid and Precise Method for Routine Determination of Organic Carbon in Soil. Communication in Soil Science and Plant Analyses, 19, 1467-1476. https://doi.org/10.1080/00103628809368027

[19] Empresa Brasileira de Pesquisa Agropecuária-Embrapa (1999) Serviço Nacional de 
Levantamento e Conservação de Solos. Manual de análises químicas de solos, plantas e fertilizantes. Embrapa Comunicação para Transferência de Tecnologia, Brasília, 370.

[20] Empresa Brasileira de Pesquisa Agropecuária-Embrapa (1997) Serviço Nacional de Levantamento e Conservação de Solos. Manual de métodos de análise de solo. 2nd Edition, Embrapa Produção de Informação, Rio de Janeiro, 212.

[21] Vance, E.D., Brookes, P.C. and Jenkinson, D.S. (1987) Microbial Biomass Measurements in Forest Soil: Determination of Kc Values and Tests of Hypotheses to Explain the Failure of the Chloroform Fumigation Method in Acid Soils. Soil Biology and Biochemistry, 19, 703-707.

[22] Joergensen, R.G. and Brookes, P.C. (1990) Ninhydrin-Reactive Nitrogen Measurements of Microbial Biomass in $0.5 \mathrm{~mol} \mathrm{~L}^{-1} \mathrm{~K}_{2} \mathrm{SO}_{4}$ Soils Extracts. Soil Biology and Biochemistry, 22, 1023-1027.

[23] Sparling, G.P. (1992) Ratio of Microbial Biomass Carbon to Soil Organic Carbon as a Sensitive Indicator of Changes in Soil Organic Matter. Australian Journal of Soil Research, 30, 195-207. https://doi.org/10.1071/SR9920195

[24] SYSTAT Software (2002) SYSTAT 10 for Windows. SYSTAT Software, Richmond.

[25] Thioulouse, J., Chessel, D., Dolédec, S. and Oliver, J.M. (1997) ADE4 Multivariate Analysis and Graphical Display Software. Statistical Computation, 7, 2-15. https://doi.org/10.1023/A:1018513530268

[26] Diaz, L. (2002) Estadistica Multivariada: Inferencia y metodos. Universidad Nacional de Colombia, Bogotá.

[27] Lima, H.N., Mello, J.W.V., Schaefer, C.E.G.R., Ker, J.C. and Lima, A.M.N. (2006) Mineralogia e química de três solos de uma topossequência da bacia sedimentar do Alto Solimões, Amazônia Ocidental. Revista Brasileira de Ciência do Solo, 30, 5968. https://doi.org/10.1590/S0100-06832006000100007

[28] Moreira, A. and Fageria, N.K. (2009) Soil Chemical Attributes of Amazonas State, Brazil. Communications in Soil Science and Plant Analysis, 40, 1-14. https://doi.org/10.1080/00103620903175371

[29] Pinho, R.C., Alfaia, S.S., Miller, R.P., Uguen, K., Magalhães, L.D., Ayres, M., Freitas, V. and Trancoso, R. (2011) Islands of Fertility: Soil Improvement under Indigenous Homegardens in the Savannas of Roraima, Brazil. Agroforestry Systems, 81, 235 247. https://doi.org/10.1007/s10457-010-9336-5

[30] Cochrane, T.T., Sánchez, L.G., Azevedo, L.G., Porras, J.A. and Garver, C.L. (1985) Land in Tropical America. 3v, CIAT/EMBRAPA/CPAC, Brasília.

[31] McGrath, D.A., Smith, C.K., Gholz, H.L. and Oliveira, F.A. (2001) Effects of LandUse Change on Soil Nutrient Dynamics in Amazonia. Ecosystems, 4, 625-645. https://doi.org/10.1007/s10021-001-0033-0

[32] Farella, N. Davidson, R., Lucotte, M. and Daigle, S. (2007) Nutrient and Mercury Variations in Soils from Family Farms of the Tapajós Region (Brazilian Amazon): Recommendations for Better Farming. Agriculture, Ecosystems and Environment, 120, 449-462.

[33] Cenciani, K., Lambais, M.R., Cerri, C.C., Azevedo, L.C.B. and Feigl, B.J. (2009) Bacteria Diversity and Microbial Biomass in Forest, Pasture and Fallow Soils in the Southwestern Amazon Basin. Revista Brasileira de Ciência do Solo, 33, 907-916. https://doi.org/10.1590/S0100-06832009000400015

[34] Numata, I., Chadwick, O.A., Roberts, D.A., Schimel, J.P., Sampaio, F.F., Leonidas, F.C. and Soares, J.V. (2007) Temporal Nutrient Variation in Soil and Vegetation of Post-Forest Pastures as a Function of Soil Order, Pasture Age, and Management, 
Rondônia, Brazil. Agriculture, Ecosystems and Environment, 118, 159-172.

[35] Nair, P.K.R., Buresh, R.J. and Latt, C.R. (1999) Nutrient Cycling in Tropical Agroforestry Systems: Myths and Science. In: Buck, I.E. and Fernandes, E.C.M., Eds., Agroforestry in Sustainable Agricultural Systems, Washington DC, 1-31.

[36] Pinho, R.C., Miller, R.P. and Alfaia, S.S. (2012) Agroforestry and the Improvement of Soil Fertility: A View from Amazonia. Applied Environmental Soil Science, 12, 1 11. https://doi.org/10.1155/2012/616383

[37] Salim, M.V.C. (2012) Quintais agroflorestais em área de terra-firme na Terra Indígena Kwatá-Laranjal, Amazonas. Dissertação de Mestrado, INPA/UFAM.

[38] Cabrera, L.T. (2009) Dinâmica da Matéria Orgânica do Solo em Ecossistemas de Floresta Secundárias sobre solos Antropogênicos e não Antropogênicos (Adjacentes) na Amazônia Central, Tese de Doutorado. INPA/UFAM. Manaus.

[39] Giardina, C.P., Sanford, R.L., Dockersmith, I.C. and Jaramillo, V.J. (2000) The Effects of Slash Burning on Ecosystem Nutrients during the Land Preparation Phase of Shifting Cultivation. Plant and Soil, 220, 247-260. https://doi.org/10.1023/A:1004741125636

[40] Mabuhay, J.A., Nakagoshi, N. and Horikoshi, T. (2003) Microbial Biomass and Abundance after Forest Fire in Pine Forest in Japan. Ecological Research, 18, 431441. https://doi.org/10.1046/j.1440-1703.2003.00567.x

[41] Luizão, F.J., Proctor, J., Thompson, J., Luizão, R.C.C., Mars, R.H., Scott, D.A. and Viana, V. (1998) Rain Forest on Maraca Island, Roraima, Brazil: Soil and Litter Process Response to Artificial Gaps. Forest Ecology and Management, 102, 291-303.

[42] Henrot, J. and Robertson, D.G.P. (1994) Vegetation Removal in Two Soils of the Humid Tropics: Effect on Microbial Biomass. Soil Biology and Biochemistry, 26, 111-116.

[43] Eaton, W.D. (2001) Microbial and Nutrient Activity in Soils from Three Different Subtropical Forest Habitats in Belize, Central America before and during the Transition from Dry to Wet Season. Applied Soil Ecology, 16, 219-227.

[44] Galicia, L. and Garcia-Oliva, F. (2004) The Effects of C, N and P Additions on Soil Microbial Activity under Two Remnant Tree Species in a Tropical Seasonal Pasture. Applied Soil Ecology, 26, 31-39.

[45] Galicia, L. and Garcia-Oliva, F. (2008) Remnant Tree Effects on Soil Microbial Carbon and Nitrogen Tropical Seasonal Pasture in Western Mexico. European Journal of Soil Biology, 44, 290-297.

[46] Luizão, R.C.C., Bonde, T.A. and Rosswall, T. (1992) Seasonal Variation of Soil Microbial Biomass-The Effects of Clear Felling a Tropical Rainforest and Establishment of Pasture in the Central Amazon. Soil Biology and Biochemistry, 24, 805-813.

[47] Bauhus, J., Khanna, P.K. and Raison, R.J. (1993) Mineralization and Nitrification in an Australian Forest Soil. Australian Journal of Soil Research, 31, 621-639. https://doi.org/10.1071/SR9930621

[48] Wardle, D.A. and Ghani, A. (1995) A Critique of the Microbial Metabolic Quotient (qCO2) as a Bio Indicator of Disturbance and Ecosystem Development. Soil Biology and Biochemistry, 27, 1601-1610.

[49] Diaz-Ravina, M., Acea, M.J. and Carballas, T. (1995) Seasonal Changes in Microbial Biomass and Nutrient Flush in Forest Soils. Biology and Fertility of Soils, 19, 220 226. https://doi.org/10.1007/BF00336163

[50] Moreira, A. and Costa, D.G. (2004) Dinâmica da matéria orgânica na recuperação de clareiras da floresta amazônica. Pesquisa Agropecuária Brasileira, 39, 1013-1019. https://doi.org/10.1590/S0100-204X2004001000009 
[51] Silver, W.L., Neff, J., Veldkamp, E., McGroddy, M., Keller, M. and Cosme, R. (2000) The Effects of Soil Texture on Below-Ground Carbon and Nutrient Storage in a Lowland Amazonian Forest Ecosystem. Ecosystems, 3, 193-209. https://doi.org/10.1007/s100210000019

[52] Sotta, E.D., Corre, M.D. and Veldkamp, E. (2008) Differing N Status and N Retention Processes of Soils under Old-Growth Lowland Forest in Eastern Amazonia, Caxiuanã, Brazil. Soil Biology and Biochemistry, 40, 740-750.

[53] Moreira, F.M.S., Nóbrega, R.S.A., Jesus, E.C., Ferreira, D.F. and Pérez, D.V. (2009) Differentiation in the Fertility of Inceptisols as Related to Land Use in the Upper Solimões River Region, Western Amazon. Science of the Total Environment, 408, 349-355.

[54] Smith, C.K., Gholz, H.L. and Oliveira, F.A. (1998) Fine Litter Chemistry, Early-Stage Decay, and Nitrogen Dynamics under Plantations and Primary Forest in Lowland Amazonia. Soil Biology and Biochemistry, 30, 2159-2169.

[55] Fernandes, S.A.P. (1999) Propriedades do solo na conversão de floresta em pastagem fertilizada e não fertilizada com fósforo na Amazônia, (Rondônia). Tese de Doutorado. Centro de Energia Nuclear na Agricultura. Universidade de São Paulo, Piracicaba, São Paulo.

[56] Alfaia, S.S., Jacquin, F. and Guiraud, G. (1995) Transformation of Nitrogen Fertilizers in Brazilian Amazonia Soils. Arid Soils Research and Rehabilitation, 9, 335 340. https://doi.org/10.1080/15324989509385902

\section{Submit or recommend next manuscript to SCIRP and we will provide best service for you:}

Accepting pre-submission inquiries through Email, Facebook, LinkedIn, Twitter, etc. A wide selection of journals (inclusive of 9 subjects, more than 200 journals)

Providing 24-hour high-quality service

User-friendly online submission system

Fair and swift peer-review system

Efficient typesetting and proofreading procedure

Display of the result of downloads and visits, as well as the number of cited articles

Maximum dissemination of your research work

Submit your manuscript at: http://papersubmission.scirp.org/

Or contact as@scirp.org 